\title{
末梢性顔面神経麻痺についての一私見
}

\author{
八木伸也
}

\section{A View on Peripheral Facial Paralysis}

\author{
Nobuya Yagi
}

(Fukui Red Cross Hospital)

Recently, the degree of facial paralysis has been described numerically using May's paralysis score method. In complete recovery, the time course of Bell's palsy can be analysed by the following equation.

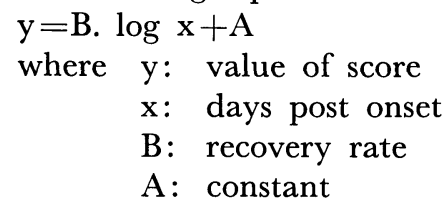

A pathological process of facial paralysis was analysed by this equation and reviewed from the "axonal flow" point of view.

The integrated EMG represents the strength of the corresponding muscle and its value indicates the degree of paralysis in facial palsy. From the study of an integrated EMG and the paralysis score method, a close relation between the two methods was revealed, with a high value of correlation coefficient. This indicates that the paralysis score method was substantiated by the objective method, namely integrated EMG. To aquire constant results, the same person should rate the paralysis score during the whole time sequence.

Because the facial nerve has several types of branches besides the main trunk, the thread lacrimation test, stapedial reflex test, and integrated EMG enable determination of the site of the lesion and the pattern of recovery. The combined use of these tests with the score method facilitates understanding of the following results.

1) When the stapedial reflex is present and do not disappear, paralysis recovers quickly.

2) Recovery from paralysis is sometimes accompanied by a high value in the thread lacrimation test.

3) The integrated EMG represents patients complaints more accurately than the score method.

1. 緒言

2. 末梢運動神経の障害と回復

3. 軸索流について

4. 顔面神経の特徵

5. 回帰直線 $\mathrm{y}=\mathrm{B} \cdot \log \mathrm{x}+\mathrm{A}$ について
6. 麻痺スコア及びその再評価

7. 諸検査について
A. 積分 $\mathrm{EMG}$ 法について
B. アブミ骨筋反射について
C. 系式流涙テストについて 
8. 附録
A. 積分 $\mathrm{EMG}$ 朋回路
B. 流添テスト用系作成法

C. 回帰分析用 BASIC プログラム

D. 顔神麻痺スコア採点表

\section{1. 緒}

言

顔面神経は耳鼻科領域の脳神経のらちよく研究されている神経であり, その麻痺は, ベル麻痺, ハント症候群等と呼ばれているが, 治癒摔が比較的良い為, 頑強な神経とされている. よく調べら れている理由として，顔面神経が側頭骨内で各種の分枝を出し，その検查が可能である事，又治癒 の経過を追いつつそれらを検討できる事情がある.

現今までの教科書を見ると，前記の各種検查を利用して，障害部位診断（局所診断）がなされる 事が多(1)2)。即ち，中枢側に位置した分枝神経の 検査が低值を示せば，その部位より以下の障害 とする考えである.

顔面神経は Fallopian canal 内位置し，豊富な血管支配をうけている．神経管内の血管支配 も上下に及ぶ anastomosis を形成している.このような部位が障害された場合，上記の如く，解 剖学的に考えて一部位が切断されたかの如く考えてよいであろらか.

最近，単純な部位診断に反する検査絬果も表われ始めている ${ }^{34)}$. 外傷等と異なり，べル麻痺等 には解剖学的な部位診断よりも血行支配や神経径を考慮に入れた診断の方が有用である事が多い。 今回我々は流涙テスト，耳小骨筋反射を用いて顔神経麻放を再検討してみた。

次に顔面神経麻痺の分析に進歩をもたらしたものとして May の麻痺スコア採点法 ${ }^{5)}$ があげられ る.この方法は一般心理学に用いられている評点法を臨㦿に持ち込んだもので，麻痺の程度をより 正確な数值として表わせるものとした.

この麻痺スコアを経過を追って附録の半対数紙に記入していくと，麻痺の経過が良くわかり他検 查法との関連も明確となってくる ${ }^{6}$. 又, 麻痺が完全回復する場合, $\mathrm{y}=\mathrm{B} \cdot \log \mathrm{x}+\mathrm{A}$ といら回復 直線によく適合するので, 数值的検討も可能となった.

ここで特徴的であることは，一度完全麻痺に陥ると，スコアが悪化していき，発症後10日目頃に 最悪となる．その後14日目より回復するといらパターンをとる．増悪がみられない場合でも，14日 目頃より回復が始まるといらパターンが多い。この理由はいろいろと考えられるが，神経回復を促 すとする軸索流の面より 1 〜 章では検討してみた.

5,6 章ではスコア解析に用いた $\mathrm{y}=\mathrm{B} \cdot \log \mathrm{x}+\mathrm{A}$ の意味づけ, 及び積分 $\mathrm{EMG}$, 流涙テスト, 耳小骨筋反射検査より顔面神経麻渒を再検討してみた.

この文は概説的なものとして記したものではなく，筆者の顔面神経麻痺発症に対する考えを記述 したものであり，独断にみちたものであることをお許しいたださたい。

\section{2. 末梢運動神経の障害と回復}

未梢神経は図 1 の如く, 神経上膜 (Epineurium) に神経束（図 1 ) (Funiculus) がつつま れており，その神経束は神経周膜 (Perineurium)につつまれている7). その内に数多くの軸 索が存在し，Schwann 細胞により形成され，
神経内膜につつまれる.

このような構造をもつ末梢神経は, 種々の原 因により障害をおこす。

末梢神経障害に対して Seddon ${ }^{8)}$, Sunderland ${ }^{9)}$ 等の分類法が広く利用されている(図 2 ). 


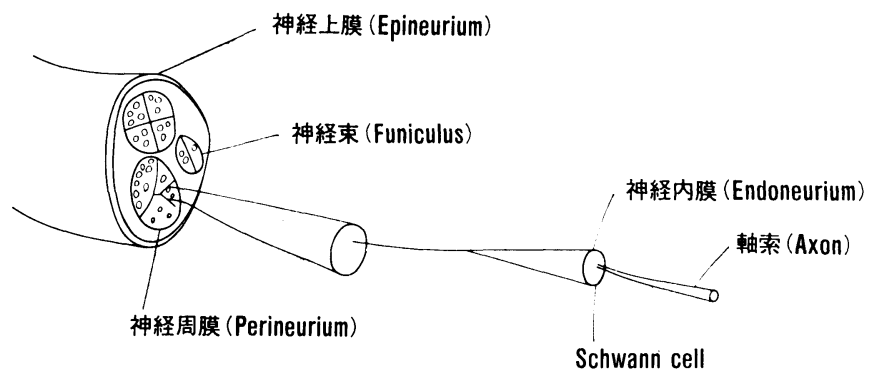

図 1 末梢神経の構造とその名称（広谷論文?) より改変)

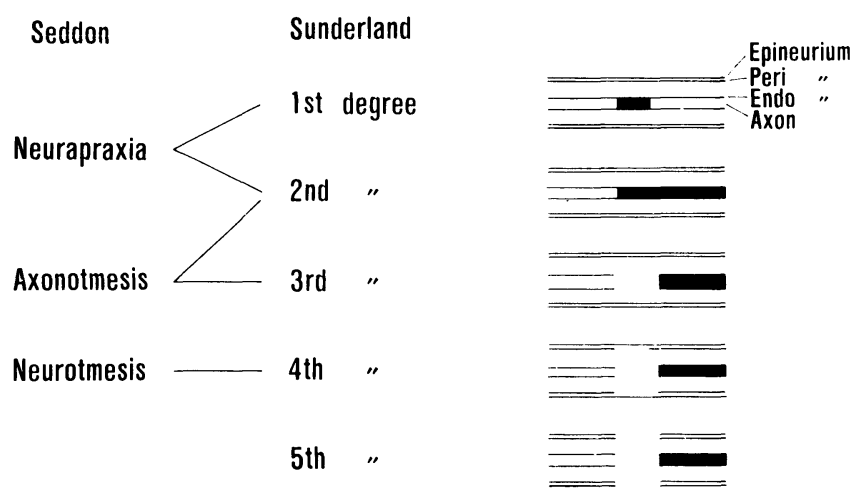

図 2 Seddon 及び Sunderland による末梢神経障害の分類

Seddon は次の 3 種類に分類した.

\section{Neurapraxia}

一番軽度の損傷であり一過性の伝導障害で ある．その本態は一過性の局存性脱髄現象で あり，生理的な block と考えられ解剖学的 な障害は残さない。

\section{Axonotmesis}

軸索は髄鞘と共に損傷部で障害されるが神 経上膜，周膜，内膜は保たれる故，再生する ための外殼は保たれており，自然回復が期待 できる.

\section{Neurotmesis}

損傷部で神経幹が断裂を起したもので連続 性が保たれず，手術療法を必要とする.

実際には上記 3 類型が種々に混合したパター ンを示す。

これに対し, Sunderland ${ }^{9)}$ は解剖学的, 病態 的考察より, 次の 5 類型に分類した.

1. 第 1 度損傷
損傷部のみにおける伝導障害で, 生理的ブ ロックであり，Neurapraxia に相当する.

2. 第 2 度損傷

軸索及び髄鞘が損傷されたもので，神経内 膜は温存される。これは, Seddon の Axonotmesis に相当する.

3 . 第 3 度損傷 神経束内部の破裂を起した場合の伝導障害 である. 神経束内の線維化が再生を障害し， 再生軸索が必ずしも本来の内膜管に到達しな いと言われる。

4. 第 4 度損傷 第 3 度損傷に加えて神経周膜も損傷された もので，神経幹の連続性は保たれているが， その中枢端に仮性神経腫を作るため自然回復 は望みがたく, 手術療法を必要とする.

5 . 第 5 度損傷

神経が完全に断裂したもので，神経上膜も 損傷されているため, 手術的に結合を必要と 


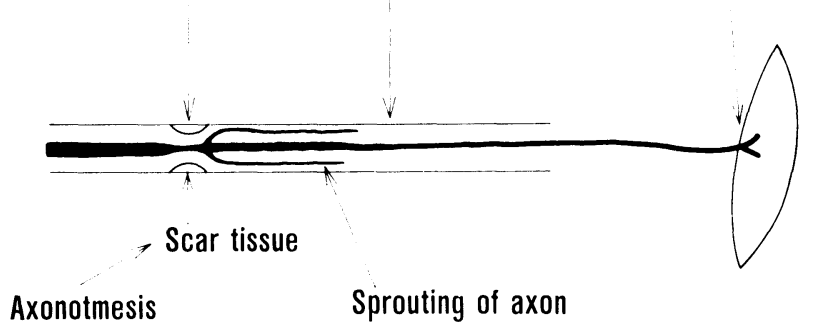

図 3 末梢神経障害後の神経回復機序

する.

これらの如く分類され，臨床的分類に忘用さ れている.

これらの損傷がいかに回復していくのであろ らか. その時期は 3 期に分けられている 13) (図 3 ).

\section{Initial Delay}

この時期は, 障害された部に生じた scar tissue をのりこえて，再生軸索がもとの管内 にのびていく時期であるが，報告者により要 する時間は異なっている. 大体 4 〜 10日と言 われている.

2. Intermediate Delay

この時期は, 再生した軸索が神経終末まで のびていく時期で, 再生速度は $1 \sim 2 \mathrm{~mm} /$ 日 と概算されている.この再生速度を軸索流と 関連づける場合が多い.

\section{Terminal Delay}

のびてきた再生軸索が，神経終末を完全に 再構成して筋力をもとに戻すまでの時期で, 5〜 7 日とされている.

再生時断裂した軸索は, scar tissue をのり こえる際に，一本の tube より10本近くの軸索 を出して伸びていき，その内の一本が残り再生 した軸索となる。この軸索がもとの管内におさ まれば完全回復となるが，他の管内に迷入する と misdirection が起る. 障害が高度である程, 顔面神経の如く支配領域のはっきりした神経は misdirection が起りやすいといえる.

ベル麻痺等の場合，上記の末梢神経障害と異 なり, Neurotmesis や第 $4 \sim 5$ 度損傷は起り えず，顔面神経管内の膨隆，圧迫による Neurapratia, Axontomesis や第 1 第 3 度障害が 起るものと思われる.

\section{3. 軸索流について ${ }^{14,15,16,17)}$ (図4)}

黒川の総説によると，最初の本格的な記述は Weiss の1948年の論文であるといら ${ }^{14)}$. 彼は 神経再生の実験中, 神経をしばることによりそ の中枢端に Knobが表われ, 除去すると消失し ていくことにより軸索流があると考え，その移 動速度は $1 \sim 2 \mathrm{~mm} /$ 日 とした.

以後アイソトープの導入により急速な発展分 化がみられるよらになったが，大別して遅い流 れ，中等度の流れ，速い流れと区別して考学ら れるよらになった。これらは，酸素環境や病的
過程により変化し, 流速も $1 \sim 500 \mathrm{~mm} /$ 日 と広

\section{軸索内輸送}

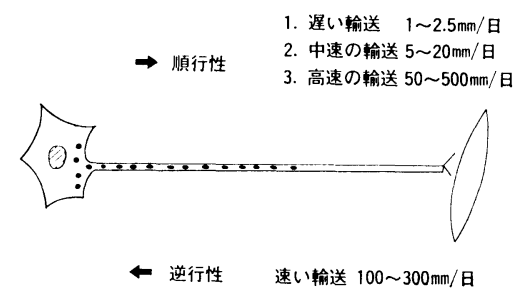

図 4 軸索内輸送の一例 速度に関して定説がない為 1 例を示す。 
く分布している.しかし遅い軸索流は軸索の再 生, 修復に, 速い方は神経伝達物質の輸送に関 与するとされている(図4).

以上よりすると, 神経再生の場合遅い軸索流 を問題とすべきであろら，末梢神経により，同 じ物質でも輸送速度が異なったり，又物質によ り異なる輸送速度を持っている為, 一概にのべ る事はできない，舌下神経や顔面神経に関する ものとして, Kreuzberg ${ }^{18)}$ の研究がある. 彼は この報告で，ラットの顔面神経を，茥乳突孔で 切断し, 顔面神経膝の直径を左右比較すると 2 日目から低下しはじめ，14日目には健側に比し - $40 \%$ の低下を示し, 以後徐々に回復するとし ている.

一方舌下神経の場合, 切断後 ${ }^{3} \mathrm{H}-$ リジンを 投与し，中枢端よりのアイントープ活性を測っ ている．報告中の図を見ると，2つのアイソト ープ活性増加がみられる.1つの峰は切断端で あるが，これは速い軸索流により運ばれた蛋白 質等であるとしている. もら一つの峰は 4 〜 $\mathrm{mm}$ のところにみられ，実際の再生に関与する 物質が蓄積する.これは48時間後の值であるの で $2 \sim 2.5 \mathrm{~mm} /$ 日の流速に相当する. 17 日後に は障害側の ${ }^{3} \mathrm{H}-$ リジンの活性が健側より高い 例がみられ, 再生線維の軸索流の亢進を示して いる. 以上の点より, 回復に必要な軸索流は

\section{Bell's palsy}

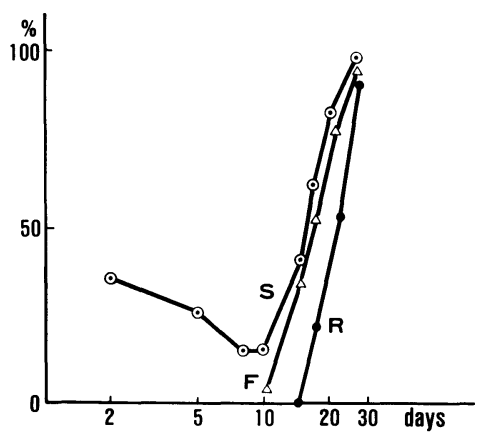

図 5

$$
\begin{array}{ll}
\text { ベル麻痺 } & \mathrm{S}: \text { スコア } \\
& \mathrm{F}: \text { 前頭筋積分 } \mathrm{EMG} \\
\mathrm{R}: \text { 职骨筋反射 }
\end{array}
$$

$2 \sim 2.5 \mathrm{~mm} /$ 日と考えられる.

軸索流を $2 \sim 2.5 \mathrm{~mm} /$ 日として，顔面神経麻 痺の例に適用してみる. 典型的な完全麻痺例を 図 5 に示す.この図にみられる如く, 完全回復 日は45日である。

45日から Initial delay と Terminal delay を ひくと, 最少 $(45-10-7)=28$ 日, 最大 $(45-4-5)$ $=38$ 日となる．2～2.5mm/日の流速より換算す ると， $56 \sim 95 \mathrm{~mm}=(28 \times 2 \sim 38 \times 2.5)$ 亿相当 し，これは顔面神経では Fallopian canal 内と なる．障害部位としては水平部あたりの可能性 が強く, $70 \mathrm{~mm}(28$ 日 $\times 2.5 \mathrm{~mm} /$ 日) 又は $76 \mathrm{~mm}$ (38日 $\times 2 \mathrm{~mm} /$ 日) の部位近くが考えられる.

このように完全回復日から逆算し，2〜2.5 $\mathrm{mm} /$ 日の軸索流を仮定すると障害は水平部近 くに存在する事となる.

又, 図にみられる如く，受診日には中等度の 麻痺スコアを示したものが，10日〜14日の間は 増悪を示し，その後に回復を示す顔面麻痺例が 多い。この事実は，Kreuzberg が膝で観察し た14日目頃に一 $40 \%$ の体積減少の事実と奇妙に も一致している.10日までの麻㽻スコアの悪化 は主に Tonus の低下による。これは何を示す のであろらか。当科ではステロイドを当初より 治療に使用している為, 增悪を示したといら考 え方も可能である.

しかし軸索流の面から考えると，障害された 部位より下の軸索流はつついており，神経も活 動している。実際，中枢よりの補給がなくな り，10〜14日で一度軸索流伝達物質が枯渴し， スコアが最悪の值を示した可能性がある.

筋シナプスの伝達物質は Ach であるので, その補給を行っている chA や protein 等の flow がある限りインパルスが多少伝達してい ると顔面運動は残る事となる．しかし flow が 枯渴してくると Tonus はさがり，麻痺スコア は低下する，これらの輸送は50〜 $500 \mathrm{~mm} /$ 日， 又, 中等度の 速度は（15 $30 \mathrm{~mm} /$ 日） と広く 分布しており，現時点では実際の障害部位を推 定する事は不可能に近い. 
完全回復日から想定した場合，遅い軸索流で 推定された障害部位は次章にのべる湊川の神経 への血管供給からすると水平部が弱いとする位 置に相当する.
䌷索流に関して，諸説が多く又臨床に応用す るには, 病態の複雑さも加わってくる為, 軸索 流のみから確定的な事は言いがたい。

\section{4. 顔面神経の特徵}

顔面神経は末梢神経の一種であるが，運動成 分, 知覚成分及び自律神経系の 3 成分を含んで いる.

顔面神経は脳幹部を出た後に内耳道に入り, 骨腔にかこまれる。途中，大錐体神経を出し， 涙分泌に関係し，アブミ骨筋枝を出して耳小骨 筋反射を制御し，鼓索神経を出して味覚を伝え る. その後, 乳突孔を出て各顔面筋を支配する. その全長の約 $40 \%$ が骨部分に被われている。こ の為, 通常の未梢神経と異なり, 制約を受ける 範囲は長い，正中神経麻痺等によくみられる拘 束部位は手根管でありこの部位で絞られると， 手根管症候群と名つけられ，この部を切開解放 すればよい，顔面神経は長い骨腔につつまれて いる為, 限られた内腔を栄養する循環系は容易 に障害を受け，又回復も技そいとえられる，管 腔内に fiber が閉じ込められている事は, 障害 が内部より起った場合, 膨隆した組織が内部崩
壊していき，構造変化を伴う Neurapraxia， Axonotmesis を起していく可能性を持ってい る事を示している.

顔面神経は Fallopian canal の全部をしめて いるのではなく, canal の内に浮いているよう な構造となっている.

Sunderland の報告2122) では，内耳道で顔面 神経の容積は12〜19\%，水平部では25〜 50\%， 垂直部で30～50\%であり，神経の他は connect ive tissue 栄養血管等の構造物を含んだ粗の結 合織である.

彼の説明によると，この管腔内がある压でバ ランスしているはずであるが，ある部分の障害 で管腔内に膨化が起ると, 循環障害が起り, 浮腫 をひき起し，これが周囲を圧迫するといら悪循 環をくりかえす。これが起る可能性は, 膝神経節 より末梢部で, 茎乳突孔に至るまでとしている.

顔面神経は垂值部では Funiculus 構造を持
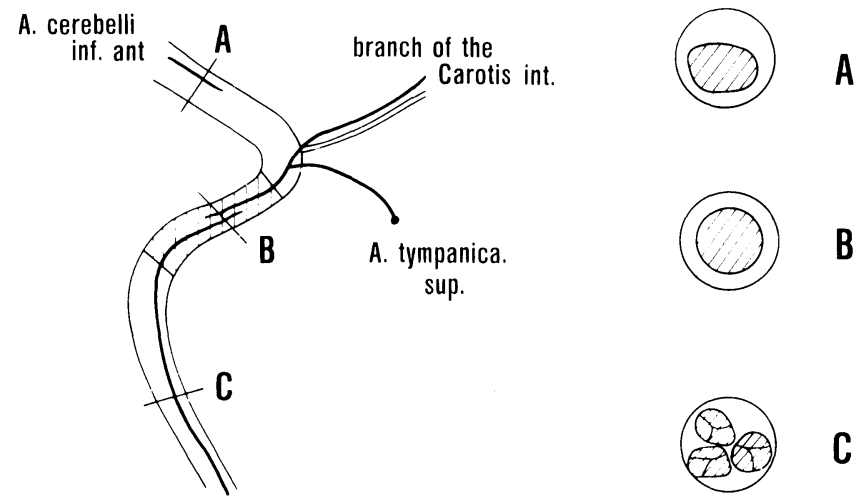

A. stylomastoidea

図 6 顔面神経の血管支配及び顔面神経管内における神経の容積 左困は顔面神経の支配血管名を示寸，水平部が，膝神経節からの血管 と, 茎乳突孔よりの血管の狭間に位置している (図中斜線). 右図は, Sunderland により示された神経管内の神経容積の概略を示す. 
っているが，水平部では Funiculus 構造を失 い，一つの神経となっていく22). Funiculus を 持っている間は緩衝帯を持っている事になる が，Funiculus 構造が消失すると容易に障害が 全周に及ぶ．水平部は解剖学的にも障害が全周 に及びやすい部位といえる。

顔面神経の内にはいろいろな size の径を持 つ神経が存在する。

Van Buskirk ${ }^{23)}$ ，Kullman ${ }^{24)}$ がその径につき

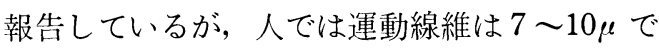
ある. 野尻によると，人の耳小骨筋を， $3 \sim 6$ $\mu$ とし，犬の場合 $2 \sim 4 \mu$ としている. 村上等 25) は最近モルモットの耳小骨筋枝の神経管内分

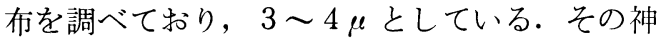
経管内走行は，管内に入った直後は周辺に存在 するが，2つに分かれ次第，内部に潜入してい く有様を報告している．いずれの報告も，耳小 骨筋は運動枝とは別の細い神経枝に支配されて おり，ヒストグラムをとると 2 峰性を示す事と なる。

側頭骨内にある神経に栄養を与える 血管系 は, 古くより研究がある ${ }^{26)}$. 漆川の詳細な研 究 ${ }^{20)}$ によると， 3 力所よりの支配をうけている

(図 6 )。茎状突孔より A. stylomastoidea が, 大錐体神経部より内頸動脈の分枝が，内耳道側 より AICA がある. Venous drainage として は, V. stylomastoidea, Meningial vein 等が ある。

この報告によると，水平部が固有の強力な vascular supply をもたず， 細い artery や vein $か ゙$ stylomastoid artery $と$ meningial system より供給されるのみで，障害を受けや すい部位である. Bell's palsy の障害はこの部 位の循環障害より起る可能性が高い。これは非 常に卓見であり，ishemia 説の有力な根拠とな る報告である。

内耳において音響性内耳障害が $C^{5}$ より起る のは既定の事実であるが，この部位は前庭蝸牛 動脈蝸牛枝及び固有蝸牛動脈吻合枝の両動脈の 狭間の部位にあり，その為障害を受けやすいと
されている27)。これは horizontal の部が両側 より循環支配され障害されやすいとする湊川の 報告と奇妙な一致を示している.

顔面神経麻㽻は中等度に発症しそのまま軽快 していく場合，Tonus 低下により増悪し完全 麻痺に変化していく場合，当初より完全麻痺で 発症する場合がある.

これらの諸相は，神経管内の局所の障害程度 により引き起されたと考えられる(図 7 ).

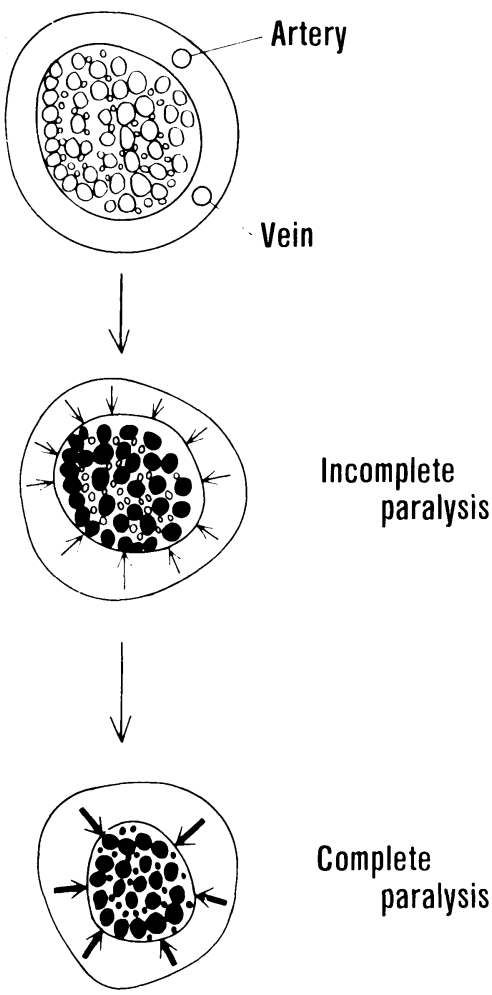

図 7 顔面神経麻痺の発症形態

上段の図は，正常な神経断面図であり各種の内压は バランスしている. 何らかの原因で浮腫等が起りバラ ンスがくずれ内圧が高まると中段の図となる．太い神 経が圧迫され, 間隙に存在する径の細い神経は障害さ れずに残り不完全麻痺を形づくる。

しかし，さらに内压が高まってゆくと下端の如く 全神経が障害され, 神経伝達は, ブロックされ完全麻 痺の状態になる. 神経の占める内容積が大きく, かつ funiculus 構造をもたない部位, 即ち水平部近くが, 障害されやすいと Sunderland はしている.

局所の浮腫が太い神経を圧迫しているが，そ の間隙にある細い神経を圧迫しない程度の浮腫 
である場合神経伝達は可能となり障害は中等度 となる.この障害は Neurapraxia 又は第 1 度 〜 2 度の障害に相当する.ここにうまく回復起 点が加わると，そのまま軽快していく，しかし 回復起点がうまくいかず，神経管内で障害が上 下に及んでいくと浮腫は高度となり，太い神経 の間に存在していた細い神経までも圧迫され，
完全な伝達ブロックが起る. この場合完全麻痺 となっていき，障害は Axonotmesis 又は 2 〜 3 度の損傷に相当する. 完全麻痺は必ず SR 消 失を伴っている. SR は運動神経 $(7 \sim 10 \mu)$ よ

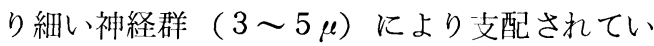
るので，細い神経障害を起すまで内圧が高まっ た結果と考えられる.

\section{5. 回帰直線 $\mathbf{y}=\mathbf{B} \cdot \log x+A$ について ${ }^{29)}$}

顔面神経麻痺が完全回復する場合，上記の式 $y=\mathrm{B} \cdot \log x+\mathrm{A}$ にそい, 注湆続的に回復 する(図 8 ).

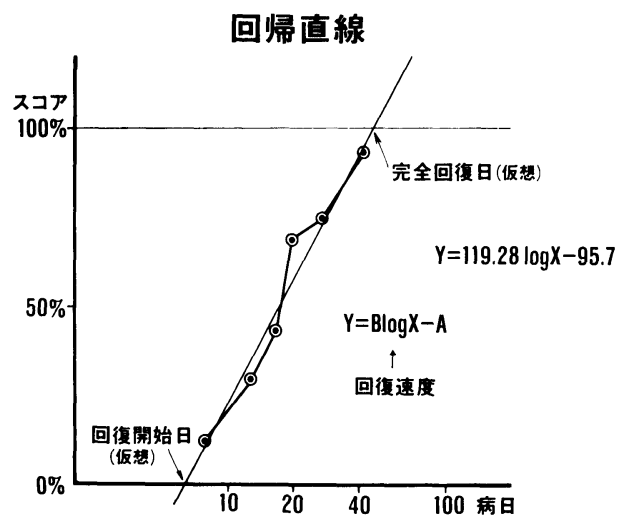

図 8 回㷌直線

スコアの回復を，回復し始めてから半対数紙に 目盛ると図の如くなる，この場合，直線をひき回 帰分析を行い, 図の如く回復速度, 回復開始日, 完全回復日を求める事が可能である.

$$
\begin{aligned}
& y: \text { スコアの值, 积分 } \mathrm{EMG}, \mathrm{SR} \text { の值 } \\
& x \text { : 病日 } \\
& \mathrm{B} \text { : 回復速度 }
\end{aligned}
$$$$
\text { A：定数 }
$$

この式は生物の回復や感覚の程度を表わすの に用いられる。

導さ方として $\triangle x$ 日毎に複利計算の如く $y$ が 増加するとして，

$$
\begin{aligned}
\Delta x & =\mathrm{C} x \\
x_{1} & =x_{0}+\Delta x_{0}=x_{0}(1+\mathrm{C}) \\
x_{2} & =x_{1}+\Delta x_{1}=x_{1}(1+\mathrm{C})=x_{0}(1+\mathrm{C})^{2}
\end{aligned}
$$

$$
\begin{aligned}
& x_{y}=x_{0}(1+\mathrm{C})^{y} \\
& \frac{x_{y}}{x_{0}}=(1+\mathrm{C})^{y} \\
& y \log (1+\mathrm{C})=\log \frac{x_{y}}{x_{0}} \\
& y=\frac{1}{\log (1+\mathrm{C})} \times \log \frac{x_{y}}{x_{0}} \\
& \frac{1}{\log (1+\mathrm{C})}=\mathrm{B} \quad \frac{x_{y}}{x_{0}}=x \quad \text { とすると,} \\
& \therefore y=\mathrm{B} \cdot \log x+\mathrm{A}
\end{aligned}
$$

以上の式は， $x$ 日毎に麻㽻が回復していき， 回復した部分が上のせされていく事を示してい る.

神経麻痺の回復は, 回復していく神経線維の 数による. 回復の早期は血行循環のよい部分か ら回復していくが，回復に取り残された細い神 経は，日時をかけてゆっくりと回復していくと 思われる. 一本の顔面神経の支配する筋肉線維 枝は，他筋に比べて少ないと言われている．ゆ っくり回復してきた一本の神経線維が回復する と, 新しい表情筋に回復が重なることになり， 上記の式の累乗の形式で表われると思われる.

実際の回帰直線の求め方は下式によった。

$$
\begin{aligned}
& \mathrm{B}=\frac{\sum\left(\log x_{i}\right) y_{i}-\mathrm{N} \cdot \bar{y} \cdot(\overline{\log x})}{\sum\left(\log x_{i}\right)^{2}-\mathrm{N}(\overline{\log x})^{2}} \\
& \mathrm{~A}=\bar{y}-\mathrm{B}(\overline{\log x})
\end{aligned}
$$

最近はマイコンや関数電卓の発達により, 容 易に回帰分析は可能となった。通常の関数電卓

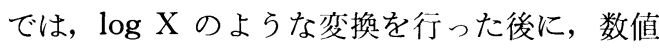
のらちこみを要するため， BASIC プログラム 
による数值計算の方が，容易である．今回はカ シオ・FX702P を用いて附録 1 の BASIC プ ログラムにより， B， A 值を求め，下記のパラ メーターを求めた。

実際に各々の回帰直線, 相関係数が求めると, $y=0$ の時に $x$ 病日は, 仮想の回復開始日とな り, $y=100 \%$ の時が仮定の完全回復日となる. 積分 $\mathrm{EMG}$ の場合は $90 \%$ となる日を完全回復日 としている，又Bは，回復速度であり，Aは定 数となる.

次に，実際の顔面神経麻痺につき，スコア $y$ と $x$ 病日の相関係数等を求めてみた.

完全回復を示した末梢性顔面神経麻痺は68例 である. 回復開始後, 各例で $4 \sim 5$ 個のポイン トが得られる.この点より，各例の相関係数よ

\section{Correlation Coefficient}

$\begin{array}{lcc} & \text { mean after stand. } & \text { simple mean \& S.D. } \\ \text { Score \& Days } & 0.9790(n=287) & 0.9726 \pm 0.026(n=68) \\ \text { Score \& Front EMG } & 0.9340(n=183) & 0.9302 \pm 0.070(n=51) \\ \text { Score \& Eye EMG } & 0.9339(n=182) & 0.9249 \pm 0.060(n=52) \\ \text { Score \& Mouth EMG } & 0.9414(n=175) & 0.9408 \pm 0.054(n=49)\end{array}$

図 9 スコアと病日，スコアと各顔面筋積分 EMG の相関係数

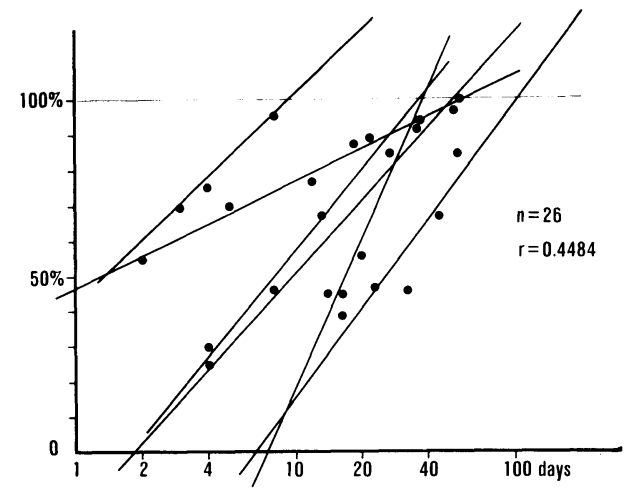

図10 末梢性顔面神経麻痺 6 例のスコアと病日の相関 各例異った経過をたどる為，単純に計算する と相関係数は低くなり，病日とスコア回復の真 の関係は求められない.
り平均，標準偏差が求められる。

実際，スコアと病日は $r=0.972 \pm 0.026(n$ =68）であった(図 9).

$4 \sim 5$ 個の值より $y$ と $x$ の真の相関係数を求 める事は統計学上不充分と言光, 又, 図10の如 く，6例でもほぼ無相関に近くなる(図10)。そ こで，各例をある日時に治癒したと仮定して， 座標変換をする．この変換中， $x$ と y の相関係 数は変らない(図11).今回は, 100 日目に完全 治癒したとした。即ち， $y=50 \log x$ の直線に なるよら $y$ を変換し，全例の $y$ と $x$ と関係を 求め，それを真の相関係数とした。 その一例を 図12に示す。

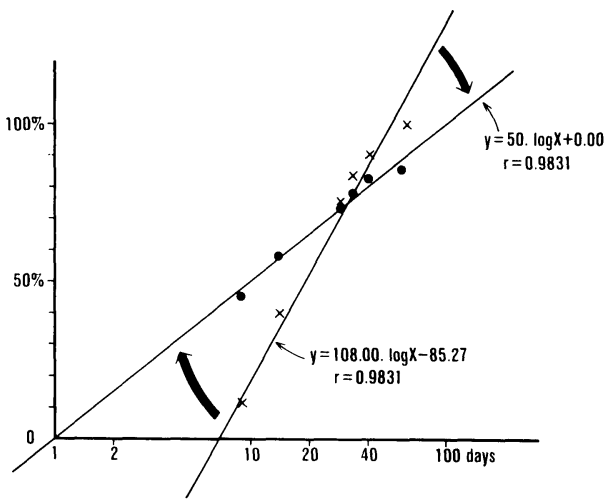

図11 回帰直線の標準化

各例を 100 日目に回復したとして座標変換 する. この変換をしても，相関係数は，元の 值に保たれる。

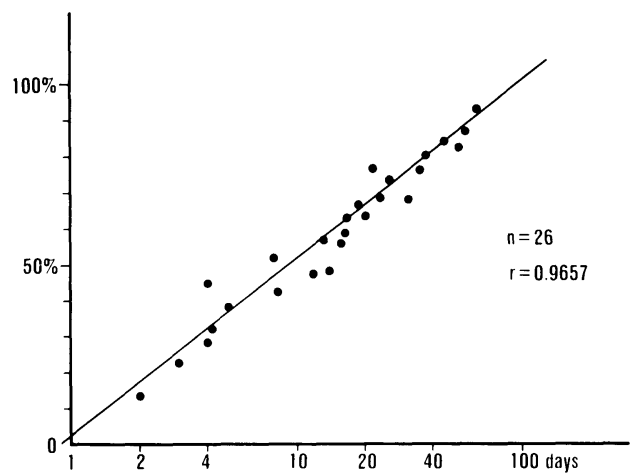

図12 スコアと病日の真の相関係数 図10に用いた 6 例をすべて標準化して，1 つの仮想回帰直線にま之めると真の相関係数 $(\mathrm{r}=0.965)$ が求められる. 


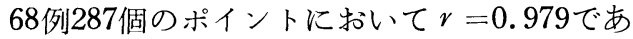
った。この值は, 上記の単純平均值よりも良い. 相関係数の 2 乗值は, 統計学上決定係数之呼 ばれ，この場合 $x$ の $y$ に対する寄与率を示す. $(r)^{2}=(0.979)^{2}=95.8 \%$ であり, $y$ の変動の 95\%をメで説明される. 残りの $5 \%$ は，スコア 決定時の判定者の主観が大きな要因となる.

以上は $y=\mathrm{B} \cdot \log x+\mathrm{A}$ のモデル式によっ た值である。

他式, $y=\mathrm{B} \cdot x+\mathrm{A}$ によるモデルも可能で ある. 日時の変化に従い, 直線的に回復すると
する式である. この式により，68例の相関係数

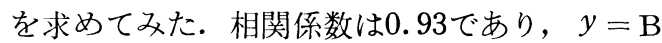
$\cdot \log x+\mathrm{A}$ の場合の值よりも低く, $y=\mathrm{B} \cdot \log$ $x+\mathrm{A}$ の式の方がよりよい相関を持っている と考穴られる.

以上の如く, 回復の分析には $y=\mathrm{B} \cdot \log x+$ A によるのが適当と思われる。これはあくま でもこのモデル式によるものであるので，他の モデルによる分析， $y=\mathrm{L}\left(1-\mathrm{e}^{-r(x-a)}\right)$ 等も 可能である.どのようなモデルがより妥当であ るかは今後の研究に待ちたい。

\section{6. 麻痷スコア及びその再評価について}

May の提唱した麻痺スコア法5) は, 従来の 方法と異なり，麻痺程度を数量として表現する ために卓越した方法であった。日本でもすぐに， 細見等 ${ }^{29)}$ ， 柳原 ${ }^{30)}$ により変法が提唱された。

May の方法は, 顔面を左右の健側, 患側に分 け，患側の度合を 3 段階又は 5 段階の評点を与 える方法である．顔面運動を10のブロックに分 け，その麻虒程度を上記の評点で表わし，総計 をもって顔面麻痺の程度とするものである.

この方法は心理学的検査としては古くから用 いられて怙り，フィシャ一の評点法と名つけら れている. 評点を与える際，人の判定基準は時 間が変っても注汇一定である事を前提としてい る. しかし心理学的判定である故に，人が変る とその判定基準が変ってくる事，又，人により 基準值から偏ったバイアスを持っている事が問 題となる.この点については, 柳原 ${ }^{30}$ 等が報告 しており，3 段階評点法の方が一般性を持つと している.

今回我々は，果して各項目に与えられている 4 点が適正な值であるか否か，補正係数を与兄 ねばならないのではないかと考光，以下の実験 を試みた。即ち柳原原法によると（表1），す べての項に一律に 4 点が与えられている。 しか しこれらの内，ある項目は麻痺を正しく表わす であろらし，ある項目はより少しの情報しか与 えないであろう。この点を重回帰分析により分

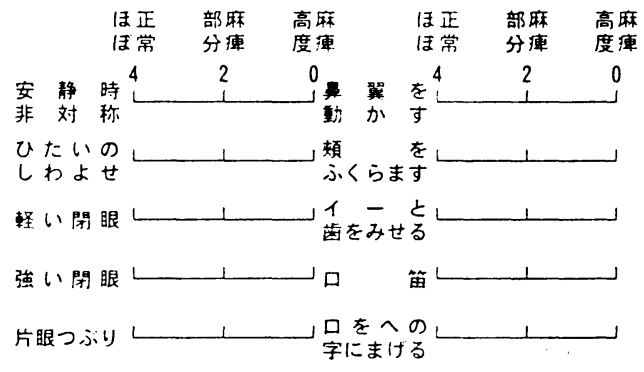

表 1

析しより望ましい評点係数を計算してみた。

検討した例は25例の完全回復を示した顔面麻 痺例である。

重回帰分析によるモデルは,

$$
y=\mathrm{B}_{0}+\mathrm{B}_{1} x_{1}+\cdots \cdots+\mathrm{B}_{10} x_{10}
$$

である. 原法のままいくと, $\mathrm{B}_{0}=0, \mathrm{~B}_{1}=\mathrm{B}_{2}$ $=\cdots \cdots=\mathrm{B}_{10}=1$ となる. 実際例のスコアより $\mathrm{B}_{0} \sim \mathrm{B}_{10}$ を求めるのが今回の目的である. $y$ の 值として, 回帰直線 $y=\mathrm{B} \cdot \log x+\mathrm{A}$ で求め られた仮想のスコア值を用いた。

25例の顔面麻痺例より平均 4 個の值が求めら れ総計 100 個あった。

例えば，18日目に 1 10項目目が $3 ， 3 ， 3$ ， $3,3,4,3,3,3$ であり，25日の仮想のスコ

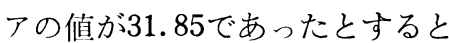

$$
\begin{aligned}
31.85 & =\mathrm{B}_{0}+\mathrm{B}_{1} \times 3+\mathrm{B}_{2} \times 3+\mathrm{B}_{3} \times 3+ \\
& \mathrm{B}_{4} \times 3+\mathrm{B}_{5} \times 3+\mathrm{B}_{6} \times 4+\mathrm{B}_{7} \times 3+ \\
& \mathrm{B}_{8} \times 3+\mathrm{B}_{9} \times 3+\mathrm{B}_{10} \times 3
\end{aligned}
$$


となる。これを 100 個の場合につき続行して， 重回㷌分析により $\mathrm{B}_{0}, \mathrm{~B}_{1} \cdots \cdots \mathrm{B}_{10}$ を求める. 分析はマイコン $(F M-8)$ により行った ${ }^{31)}$. 結 果は

$\begin{array}{lll}\mathrm{B}_{0} & 1.3334 & \\ \mathrm{~B}_{1} & 0.7409 & \text { 安静時非対象 } \\ \mathrm{B}_{2} & 1.0192 & \text { ひたいのしわよせ } \\ \mathrm{B}_{3} & 0.9575 & \text { 軽い閉眼 } \\ \mathrm{B}_{4} & 1.3760 & \text { 強い閉眼 } \\ \mathrm{B}_{5} & 0.6718 & \text { 片眼つむり } \\ \mathrm{B}_{6} & 0.8255 & \text { 鼻翼を動かす } \\ \mathrm{B}_{7} & 1.0611 & \text { 頓をふくらます } \\ \mathrm{B}_{8} & 1.5550 & \text { イーと歯をみせる } \\ \mathrm{B}_{9} & 0.6634 & \text { 口笛 } \\ \mathrm{B}_{10} & 0.6437 & \text { ロをへの字にまげる }\end{array}$

であった。

以上のことは強い閉眼と，イーと歯を見せる の項目が与学る情報量が多く, 安静時非対象, 片目つぶり，口笛，口をへの字にまげるの項目 は，今まで考えられたより少い点数で良い事を 意味する，再配点してみると

$\begin{array}{cc}40 \text { 点満点 (図13) } & 100 \text { 点満点 (図14) } \\ x_{1} \text { の項-3点 } & 8 \\ x_{2} \text { の項 }-4 \text { 点 } & 10 \\ x_{3} \text { の項 }-4 \text { 点 } & 10 \\ x_{4} \text { の項 }-6 \text { 点 } & 15 \\ x_{5} \text { の項-3点 } & 7 \\ x_{6} \text { の項-4点 } & 8 \\ x_{7} \text { の項 }-4 \text { 点 } & 12 \\ x_{8} \text { の項 }-6 \text { 点 } & 16 \\ x_{9} \text { の項-3点 } & 7\end{array}$

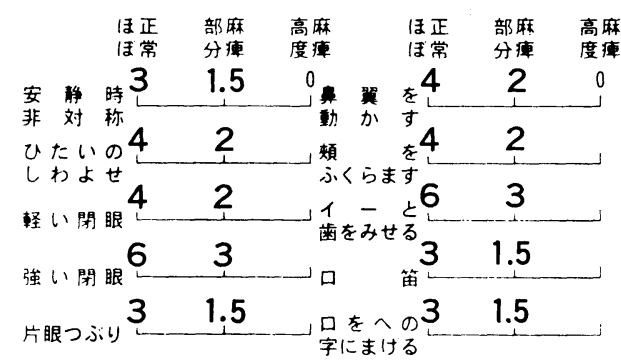

図13 40点法で再配点した麻痺スコア表

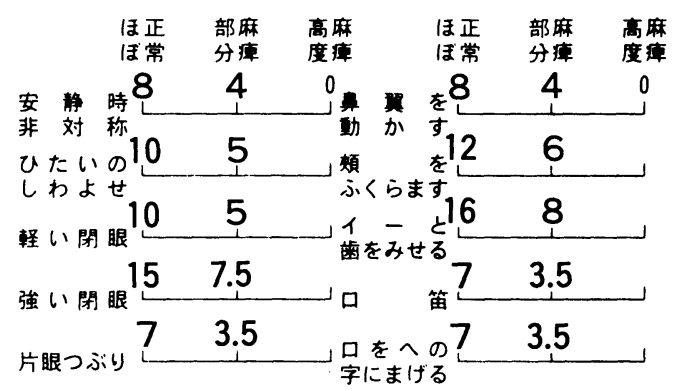

図14１00点法で再配点した麻痺スコア表

$$
x_{10} \text { の項- } 3 \text { 点 }
$$

となる。

$\mathrm{B}_{0}$ は個々人が持っている心理的バイアスの 度合のようなもので，除き難いものと思われ る.これらの值は，筆者が判定者として判定を 行った場合の特殊例であるので, 他の判定者が このような值を与えるか今後の検討を要すると 思われる。

通常の臨床では 5 段階法 (4 点均一) で充分 と思われるが，より精密な分析を行らには $y=\mathrm{B} \cdot \log x+\mathrm{A}$ を基準とすると, 上記の如 く配点を変化させた方がよいと推察される。

\section{7. 諸検査について}

以下の節では，当科で行っている検査法を概 説してみる. 検査法として, 積分 EMG 法, 耳 小骨筋反射検査，流涙テストをとりあげる，以 下に述べるが積分 EMG 法はスコア法を客観的 に裏付けるものであるといら事であり，耳小骨 筋反射にみられる特長は, 障害程度が神経径の 太さの障害によるといらことである.
流涙テストは自律神経系の支配下にあるため 又別の解积が必要であるが，当科で行っている 糸式流涙テストでは従来の Shirmer 法とは異 なった事実をみつけた故に，それ中心に記して みる.

\section{$7 \mathrm{~A}$ 積分 EMG 法について ${ }^{6)}$}

積分 EMG は, ほぼその筋の筋力と比例す 
るといら報告が，1952年，Lippold ${ }^{32)}$ によりな された。彼は用手計測で積分を行ったが，現今 では $\mathrm{AC}-\mathrm{DC}$ 変換器で容易に $\mathrm{AC}-\mathrm{DC}$ 変换 が可能となった.

通常の EMG は Spike が重なった複雑な波 形で専門家にも判定しにくい事が多い。この Spike を積分していくと，変換波の高さは筋力 に比例したものとなる。

積分とはある区間の情報をすべて加えていく 事であるので，ここに述べる積分 EMG 法とは 適確な名称ではないかも知れない。附録Aに見 られる如く，ここに述べる積分 EMG とは通

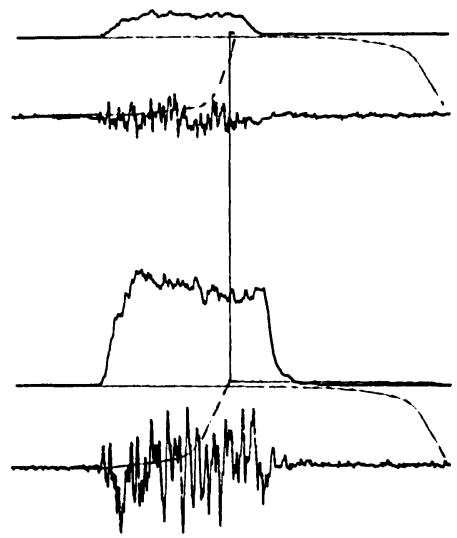

図15 積分 EMG の 1 例 上図は麻痺側の EMG (下段) と積分 EMG (下段)， 下図は健常側の EMG (下段) 及び積分 EMG (下段)

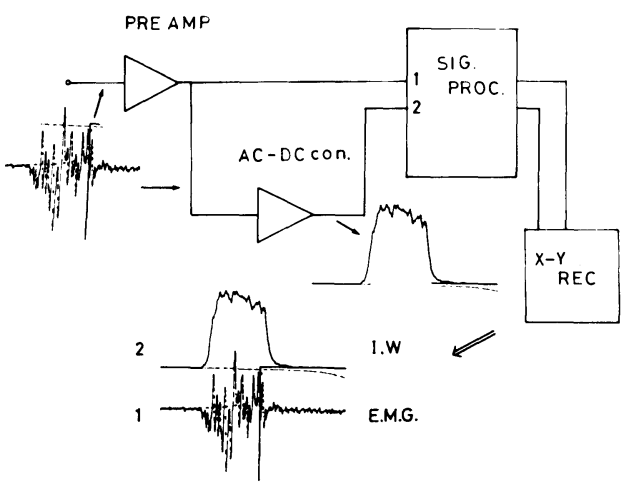

図16 積分 $\mathrm{EMG}$ を得る為のシステム プリアンプで，通常の EMG を記録する. 原波 形を, AC-DC 変換器に通すと図の如く台形波と なる、これを X-Y レコーダーにて書き出す.
常の $\mathrm{EMG}$ を $\mathrm{AC}$ - $\mathrm{DC}$ 変換して得られたも のである(図 15, 16). AC-DC 変換とは, $\mathrm{EMG}$ に含まれる $\mathrm{AC}$ 成分を $\mathrm{DC}$ 成分, 即ち 台形波に变換する技法である. DC 変換後に得 られる波形は，平均值応答である，厳密な意味 で平均值応答を得るには， RMS-DC 変換器 を使わねばならないが，今回は生体計測を目的 とし, 又左右比較するのであるから， AC-DC 変換器を用いた方法で十分な精度が得られた。 今回の方法は平均值 $\mathrm{EMG}$ 法と名付る方が妥当 であるかもしれないが，従来通り積分 EMG法 と名づけ拉く.

通常の EMG を皿電極で，前頭筋，眼輪筋， 口輪筋より 双極誘導にて左右より得る.この 時，「前頭部にしわをよせる」，「眼をしっかり つぶる」，「口をとがらせる」等の指示を与える と，図の如くの台形波となる.

注意せねばならないのは，この時患者に左右 同等の力を与えるつもりでするように指示する 事で，これを意ると異常に低い值が出る事が多 い. 積分 $\mathrm{EMG}$ によると正常人でも左右差が見 られる為, 顔神麻痺の場合正常側の $90 \%$ となっ た時を回復完了とした.

本章の目的は，スコア採点法が客観的に妥当 であるか否かを検討する為に，積分 EMG 法を 用いて行った事である.

前回の報告6) ではスコアと積分 EMG の相関 は 0.85 であるとした.この相関係数は医学上 では十分な相関といえる.スコアと病日の関係 に見られた如く，各例が異った回復を示すので あるから，単純に全部の平均をとり相関係数を 求めると各例間の䛊差がくりこまれて，相関係 数は分散を示してくる. この為, 真の相関係数 を求めるには，前章でのべた如く積分 EMG の 回復をある基準線に変換し，相関係数を求める 事が必要となる. 今回の場合， $y=x$, 即ちス コアが100\%回復すると積分 EMG も $100 \%$ 回 復したとした。

変換前の相関係数は下記の如くであった（図 9 ). 
スコアと前頭筋

0.9302

$n=51$

スコアと眼輪筋

0.9249

$n=52$

スコアとロ輪筋

0.9408

$n=49$

一方, 変換後の相関係数を示すと,

$\begin{array}{lll}\text { スコアと前頭筋 } & 0.9340 & n=183 \\ \text { スコアと眼輪筋 } & 0.9339 & n=182 \\ \text { スコアと口輪筋 } & 0.9424 & n=175\end{array}$

である.

以上の如く，スコアと積分 $\mathrm{EMG}$ は非常に良 い相関を示し，これはスコアが客観的な方法に よる裏付けを持っている事を示す。

次に積分 $\mathrm{EMG}$ の利点は, この他の患者の訴 えをよく表わす事が多い，という事である.

完全回復を示したと思われる患者で積分 EM G を施行すると，積分 EMG の值が多少低い 值を示している事が多い，たずねてみると，

「何となく力が入らない」といら返事が返って くる，一見回復したように見えても，筋力の回 復は不十分なのである（図17）。積分 EMG の 回復值は通常10 20日位遅れるのが一般的であ る. 故に, 患者には積分 $\mathrm{EMG}$ の回復直線から 予想される回復日時と, スコアの回復直線から 予想される日時の中間值を告げることが多い。

\section{B アブミ骨筋反射について ${ }^{33)}$}

音響負荷のコンプライアンス変化は耳小骨筋, それもアブミ骨筋反射によるとの考光により，
耳小骨筋反射, 又はアブミ骨筋反射 (Stapedial, Reflex, SR) と名付けられている. この反射に アブミ骨が大きく関与している事は間違いない が，他の耳小骨筋も関与している可能性もあり 両者の名前が筆者の好みにより使われている. 今回は，アブミ骨筋反射 SR とする.

この $\mathrm{SR}$ は $110 \mathrm{~dB}$ 近くまで音圧の増加に比 例して反射振ゆの増大を示す直線性を示す領域 がある(図18)。この直線性を示す領域内で左右 差を比較すると，顔面神経麻痺の場合，耳小骨 筋の麻痺程度を示すこととなる. しかし正常人 の約70\%は左右差を示さないが，約30\%は，左 右差を示すので，この事に留意しつつ，結果を 比較検討しなければならない33).

顔面神経麻痺の場合，SR の経過は病態に対 応して種々の反応を示す．表にみられる如く， $\mathrm{SR}$ が残存しから途中で消失しない場合不完全 麻痺となり回復は早い(図20).

しかし一旦，SR が消失すると顔神麻痺は完 全麻痺となりSR の回復は遅れる。回復がみら れるよらになると， SR はスコア及び積分 $\mathrm{EM}$ G の回復に追いつき，完全回復する（図19).

これが一般的な傾向である。

図復開始日を $\mathrm{SR}$ と積分 $\mathrm{EMG}$ の両者につ きヒストグラムを表示したものが図21である. 図22にはその表示を裏返しにして示している。

\section{Frontal EMG}

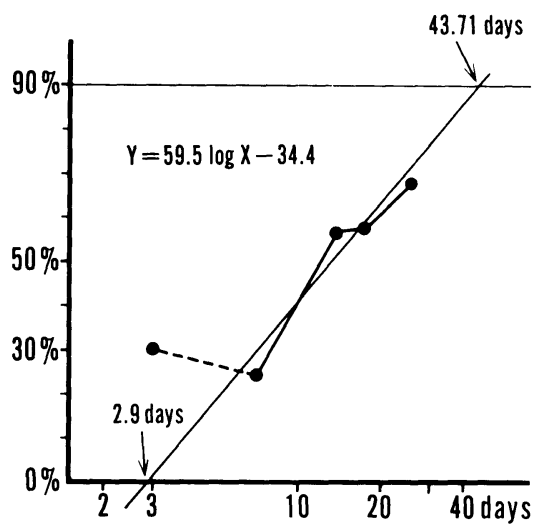

\section{Mouth EMG}

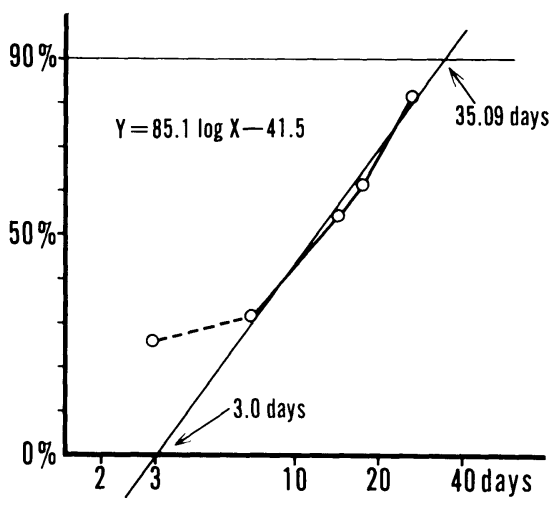

図17 積分 EMG の回㷌直線 


\section{S. R $\quad 90_{\mathrm{dB}} \quad 95_{\mathrm{dB}} \quad 100_{\mathrm{dB}} \quad 105_{\mathrm{dB}} \quad 110_{\mathrm{dB}}$}
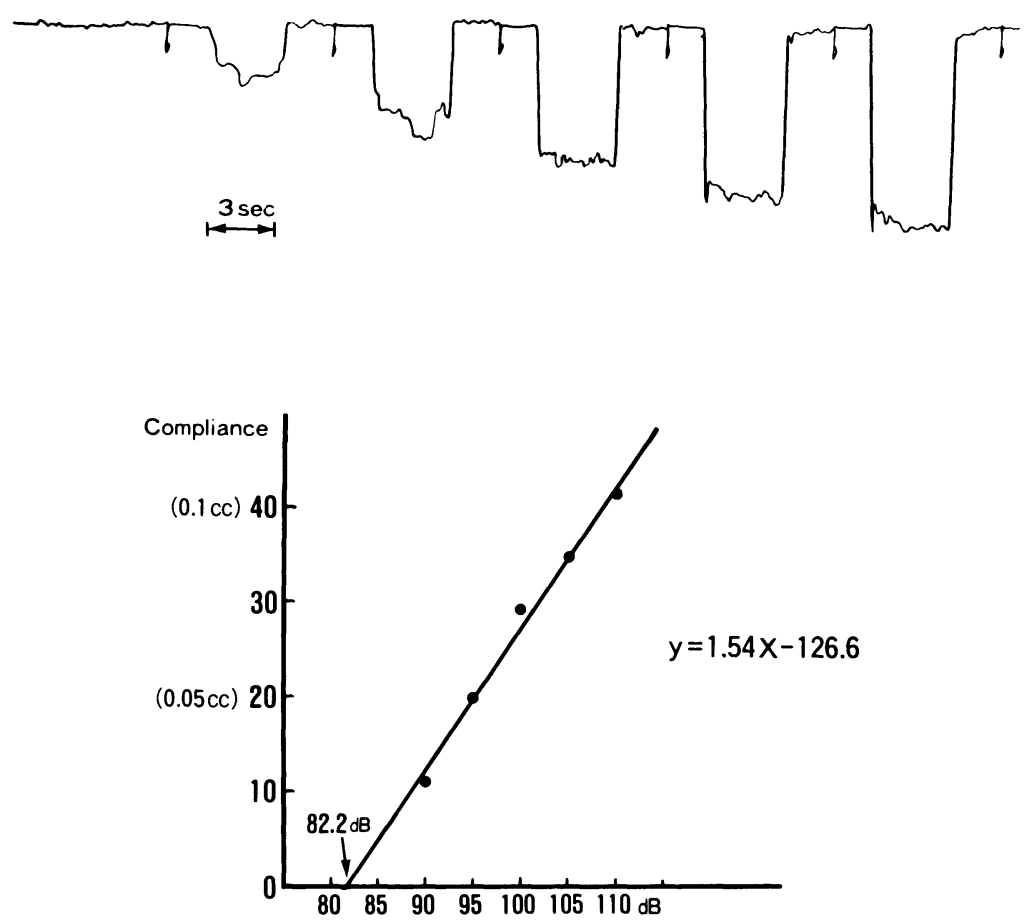

図18正常人の耳小骨筋反射

上図は，SR の原波形を示す，下図にその振巾を音圧に対して示したもの である. 音压 $110 \mathrm{~dB}$ 近くまでは, ほぼ入出力関係は, 直線を保っている. この領域の左右比を求めて麻疩時の SR 值とした.

\section{Bell's palsy}

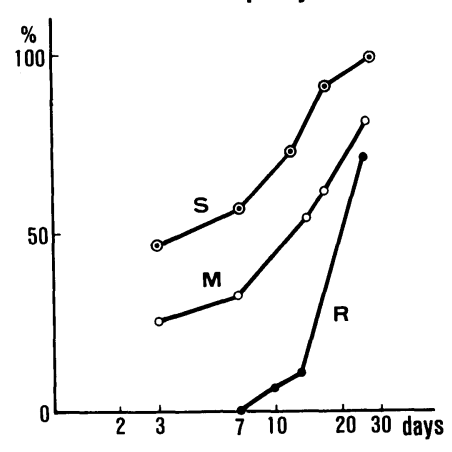

図19 ベル麻渒のスコア，積分 $\mathrm{EMG}, \mathrm{SR}$ の回復例

Reflex は遅れて回復し始めるが, 回復速度が早い事がわかる.

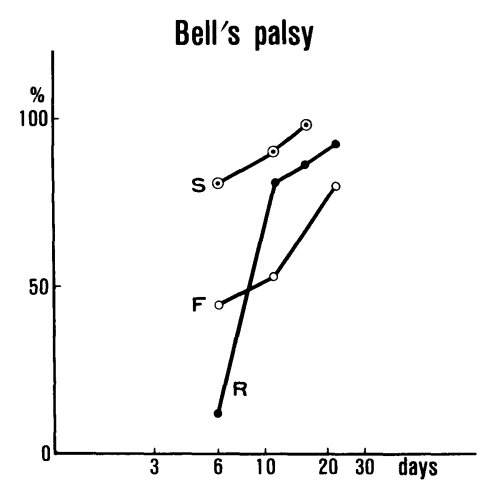

図20＼cjkstart不完全麻渒例のスコア，積分 EMG， $\mathrm{SR}$ の回復例

不完全麻痹の場合, SR は残存し消 失する事なく回復してゆく. 

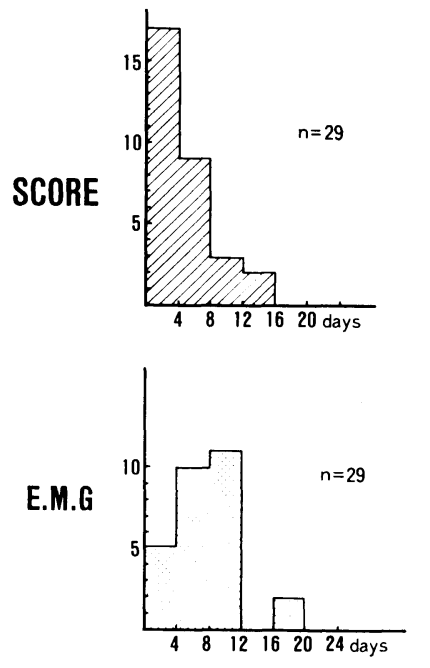

S.R

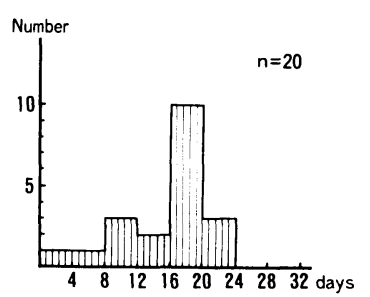

図21 スコア, 積分 $\mathrm{EMG}, \mathrm{SR}$ の回復開始日のヒストグラム分布 積分 $\mathrm{EMG}$ と, SR は 2 つの峰を形成する.

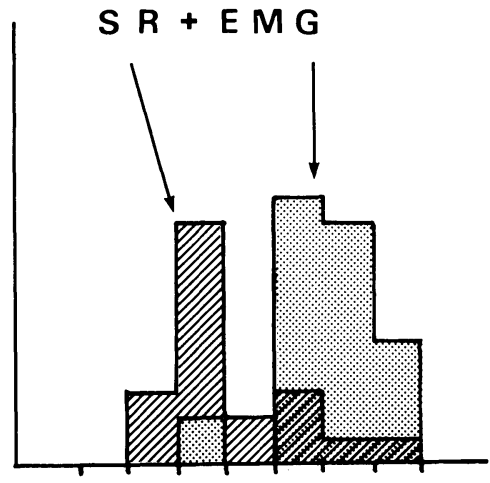

図22 積分 $\mathrm{EMG}$ と SR の回復開始日の分布 図 21 中の積分 $\mathrm{EMG}$ 及び SR の回復を重 ね合わし，裏返しにするとこの図となる.

図にみられる如く, 積分 $\mathrm{EMG}$ は顔面運動 枝, SR は耳小骨筋枝に相当するので, 通常 の運動枝と耳小骨筋枝は 2 つ峰（即ち $2 つ$ の神経径)をもつと推察される.

この図にみられる如く，SR と积分 $\mathrm{EMG}$ は 2 峰性の分布を示す.これは何を意味するので あろらか。完全麻痺に障害を受けた神経径と咸 連しているようである(図23)。

人の場合 Buskirk ${ }^{23)}$ は運動数を 7-10 とし

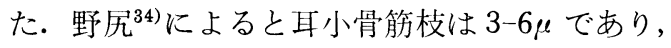
運動枝よりも細い.アブミ骨筋枝と通常の運動 枝の直径をヒストグラム表示すると，2 峰性の

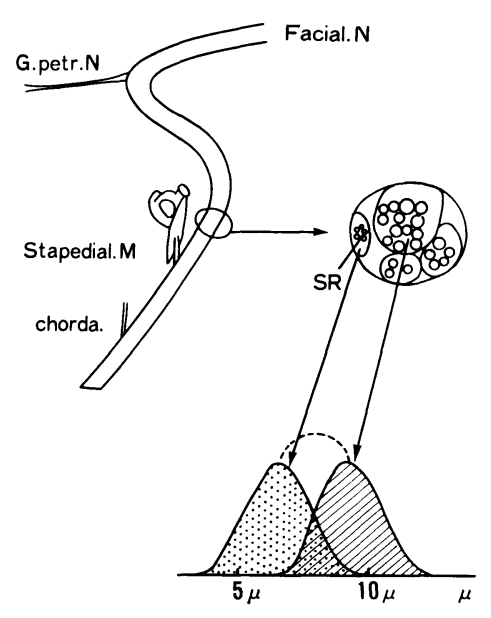

図23 耳小筲筋枝と顔面運動枝の模式図

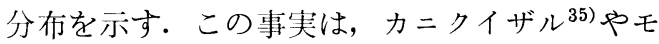
ルモット ${ }^{25)}$ でも観察されている.

この 2 峰性の分布が, SR と積分 $\mathrm{EMG}$ の七 ストグラムでもみられた事は，次の事を予想さ せる。

顔面神経僺算の場合障害が神経管内全部に及 ぶと, 細い神経径の部分も障害される. SR も 消失し，スコアの值も低下する. 回復が起る時 期になると，障害された順序と逆方向に回復が 起り, 一旦回復し始めると, 細い神経径の回復 
は表面積の点から太い神経より有利であると考 えられる。

村上 ${ }^{25)}$ は，モルモットでアブミ骨筋の直径及 び走行を調べているまず筋をはなれたあと顔 面神経管内にはいり，顔面神経の表層を 1 本の funiculus として走行する. それから 2 本にわ かれ，徐々に神経内に消えてゆく.アブミ骨筋 枝が表層に funiculus として存在することは， 中央の顔面神経の浮腫が消失し始めると，中央 に存在する神経群より回復に有利である事をら かがわせる.

この事は，顔面神経麻痢に際して，一度完全 麻㫌を起した場合，SR の回復開始は遅れるが，

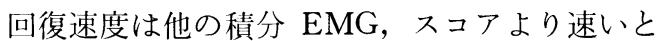
いら事実を説明する。

以上顔面神経は，障害が中等度で太い神経の 間隙に存在する細い神経が健在であると不完全 麻痺となる，障害が大きくなると細い神経にま でそれが及び SR は消失するが，一旦回復し始 めると, 回復速度は表層に近い循環環境の良い 位置にある程良いといえようか。

\section{$7 \mathrm{C}$ 系式流涙テストについて ${ }^{37)}$}

涙腺は，顔面神経の一分枝である大錐体神経 からも支配を受けている。この為，流淚機能検 查が，麻痺の部位診断，障害度診断に用いられ ている. Shirmer 法は, 涙腺機能のらち流涙 速度を測定する為に開発された。

しかしこの Shirmer 法には，次の如くの欠 点がある１１，下眼瞼にかける為，麻痺の為に

\begin{tabular}{|c|c|c|}
\hline & Shirmer法 & 系式流涙テスト \\
\hline 料 & 巾 $5 \mathrm{~mm}$ の沪紙 & 綿 系 \\
\hline 插入部位 & 下結膜円蓋 & $\begin{array}{c}\text { 上結膜円蓋 } \\
\text { (外側) }\end{array}$ \\
\hline 計測時間 & 5 分 & 1 分 \\
\hline 検 & $\begin{array}{l}\text { 下眼瞼に貯留したた } \\
\text { 滬液も測る為不安 } \\
\text { 定。 }\end{array}$ & $\begin{array}{l}\text { 涙腺直下に置くた } \\
\text { め真接涙腺能が } \\
\text { 測定できる。 }\end{array}$ \\
\hline 測定液量 & $\begin{array}{l}\text { 多量。反射性流滬 } \\
\text { を要す。 } \\
(0.76 \mu \ell / \mathrm{mm})\end{array}$ & $\begin{array}{l}\text { 微量で可能 } \\
(0.054 \mu \ell / \mathrm{mm})\end{array}$ \\
\hline
\end{tabular}

図24 Shirmer 法と系式流涙テストの比較
貯留した沪液をはかる事，2，口紙を吸水物と して使用している為, 涙液としては多量を必要 とする. 3.5 分間もの長時間がかかる事で ある.これら特に 2 の為に Shirmer 法の成績 は，再現性に欠けている事が多い。これに代る ものとして，1975年栗橋等 ${ }^{38)}$ は糸式流沪テスト を発表した（図24）。これは脱脂したフルオレ スチン染系を外眼瞼の主沪腺下に直接挿入する もので，30秒間の短時間で再現性のあるもので あるとした．実際この方法は，上記の欠点を補 っており，系作成の労をいとわなければ，無害 で，正確であり，再現性のある方法で，筆者も ての方法を愛用している，系式流涙テストの利 点は，脱脂した系を利用したところにある. Shirmer 法で用いられている口紙を用いると $1 \mathrm{~mm}$ 長を得るために0.76 $\mu l$ の液体が必要で あり，系の場合は $0.054 \mu l$ で十分である．0.5$2.0 \mu / \mathrm{min}$ の涙液を検出するには，糸式は有効 な方法である。

系式沪流テストで顔面神経麻痺の経過を観察 する図 $25,26,27,28$ の如くなる. 正常人 42 名に よる流涙テストの正常範囲は， $\pm 40 \%$ であるの で，140\%以上を hyper 型，60\%以下を hypo 型，中間にあるものを normal 型とした。

今までの Shirmer 法を利用した報告では， hypoの記述が多く hyper 型の記述は少ないが が，糸式の場合は，56\%にも達している，それ

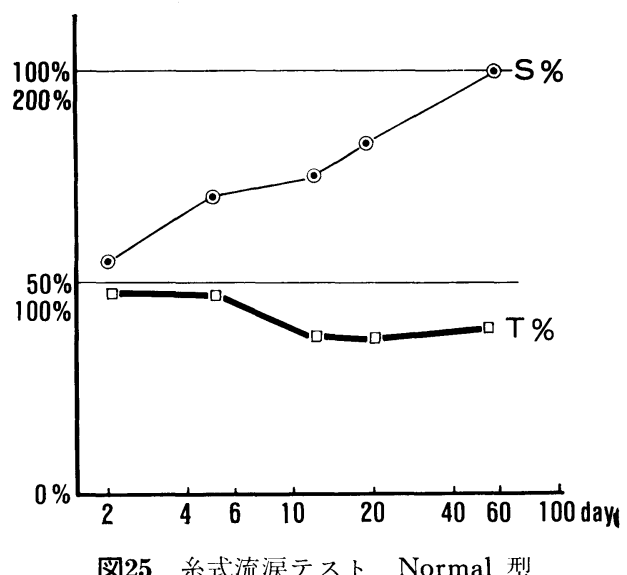

図25 系式流涙テスト Normal 型 

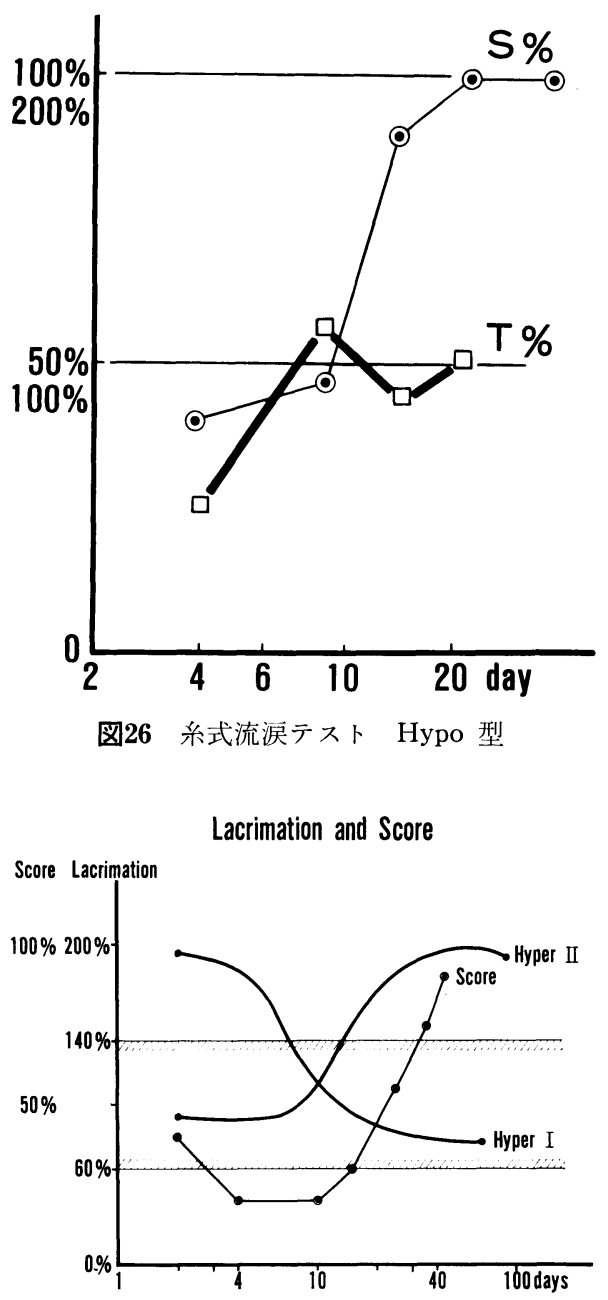

図27 系式流涙テスト Hyper 型 $140 \%$ 以上に上昇した型には 2 型ある. Hyper I 型は鬼眼の存在した時期に Hyper となった型 であり，角膜刺激による反射性流涙が考えられる。 Hyper II 型は，スコアが回復し鬼眼が消失し始め る時期に増加して扣り，麻痺回復の何らかの機序 に関与しているようである.

も麻痺初期にみられる Hyper I 型と, 麻痺回 復期にスコアと共に上昇する Hyper II 型にわ けられる. 麻痺初期に hyper がみられる例で は, 鬼眼を伴っている為, 本来の意味で Hyper 型となっているか否か不明であるが, Hyper II 型は，スコア回復に先行して流沪増加が起っ ており, 鬼眼も消失し始めている為, 涙腺の機

\begin{tabular}{|l|c|c|c|}
\hline & ベル & ハント & 計 \\
\hline Normal & 9 & 1 & $10(29.4 \%)$ \\
\hline Hypo & 3 & 0 & $3(8.8 \%)$ \\
\hline Hyper & 15 & 4 & $19(55.9 \%)$ \\
\hline Others & 1 & 1 & $2(5.9 \%)$ \\
\hline & 28 & 6 & $34(100 \%)$ \\
\hline
\end{tabular}

図28流涙テストに拈ける各型の分布 Hyper 型が 55.9\% と多く, Hypo 型が $8.8 \%$ と少ないのが特長である.

能六進が起っている可能性は存在する.

顔面麻痺での流涙増加は, $\mathrm{Ga}$ シンチを用い た涙腺機能検査でも確認された ${ }^{40)}$.

この流涙増加は何を意味しているのであろう か.

顔面神経麻痺の回復期には，神経支配下にあ る顎下腺でも流量が増加すると東辻 ${ }^{39)}$ は報告し ている.

同じ神経の支配下にある同様の分泌腺が，同 じょうな結果を示している事は, 顔面神経回復 に際して起った現象を異る器官でながめている とみた方が妥当である.

神経再生を促す因子と，流涙増加をもたらす 因子が同じとすれば，やはり顔面神経内に存在 する軸索流の考えがあてはまろう，再生を促す 1 日 $1 \sim 2.5 \mathrm{~mm}$ の軸索流は，大錐体神経を介 して, 流涙増加となってあらわれたと考える余 地も残されていよう.

\section{附録 $\mathbf{A}$}

積分 EMG 用回路

この回路は，基本的には全波整流回路であ る. 入力を, 理想ダイオード 回路で半波整流 後, 原波形に加え合わせている.この回路は, 一般的な $\mathrm{AC}-\mathrm{DC}$ 変換器であるので, 㛜密な 意味の平均值ではない, 必要ある場合は専用の RMS-DC 変換用 IC (AD 536 等) を用いる 必要がある.しかし今回の目的には, $\mathrm{IC}_{2}$ のC $(1 \mu \mathrm{F})$ を変更する事で適当な波形が得られる. 


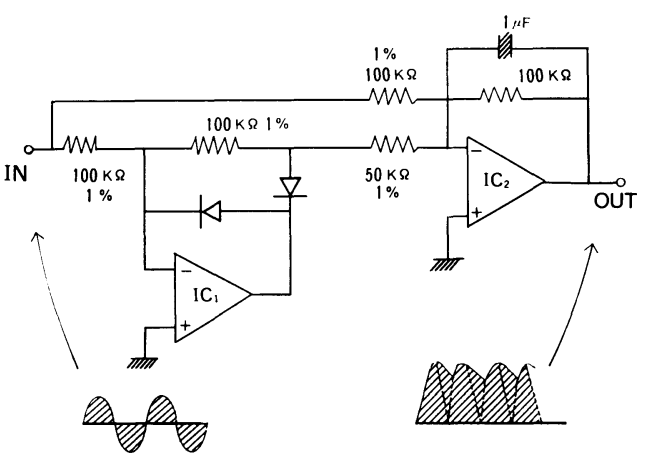

附図 1 AC-DC 変換用回路

\section{附録 B}

流涙テスト用系作成法

1. $100 \%$ 綿糸 30 番を $10 \mathrm{~cm}$ 長に切り, 50 本くら いを束ねる。

2.その束ねた糸を，70\%アルコール $+70 \%$ エ チルェーテルに24時間浸しておく.

これは綿系の脱脂に欠くべからざる過程であ る.

3. 束ねた糸をとり出し乾燥させ, フルオレス チン原液に，系の一端をひたすよらにする。

糸により長く染る場合もあるが，使用時に切 断できるので全端をそめるようにする.

4.フルオレスチン糸をドライアー等で乾燥さ せる。

5.フルオレスチン糸をオートクレーブ消毒す る.

6. 消毒されたフルオレスチン糸を流涙テスト に使用する。

この流涙テストのポイントは, 涋液が系に十 分吸収されるようにする為, 水分吸収を妨げる 脂肪分の混入をさける事である．故使用の度每 に手でさわらぬよらピンセットで系を 2 本とり 出し, 清潔なハサミでフルオレスチン端を $5 \mathrm{~mm}$ $-10 \mathrm{~mm}$ くらいに切りとる. この長さは, 外側 上眼瞼の下に入れた時外に出ないよらにする為 で，特別な意味はない。

\section{附録 C}

回帰分析用の BASIC プログラム

3 個以上のデータを入力した後, $y=\mathrm{B} \cdot \log$ $x+\mathrm{A}$ の式により， $\mathrm{B}, \mathrm{A}$ 值を求めるプログラ ムである. カシオ FX-702P 用の BASIC で ある為, 特殊な命令がある. DATA1にデータ 数, DATEに $x$ 病日， $y$ にスコアや積分 $\mathrm{EMG}$ の值を入れてゆく，データを入力し終ると， $y=\mathrm{B}($ プログラム中 $\mathrm{LRB}) \cdot \log x+\mathrm{A} \quad$ (プロ グラム中 LRA）がプリントされる. 続いて， 回復開始日 “START”，100\%回復日 “RECO $\mathrm{V}=”, 90 \%$ 回復日 “EMG =”, 相関係数 “COR =”が出力される.

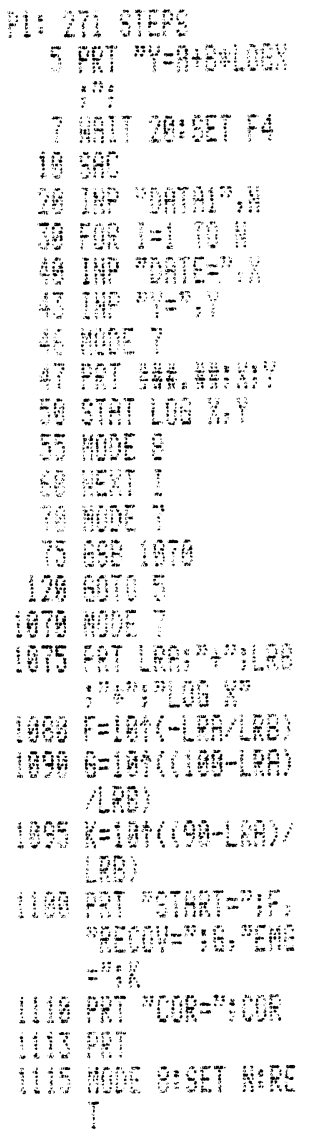

附図 2 回㷌直線用プログラム 
附録 D

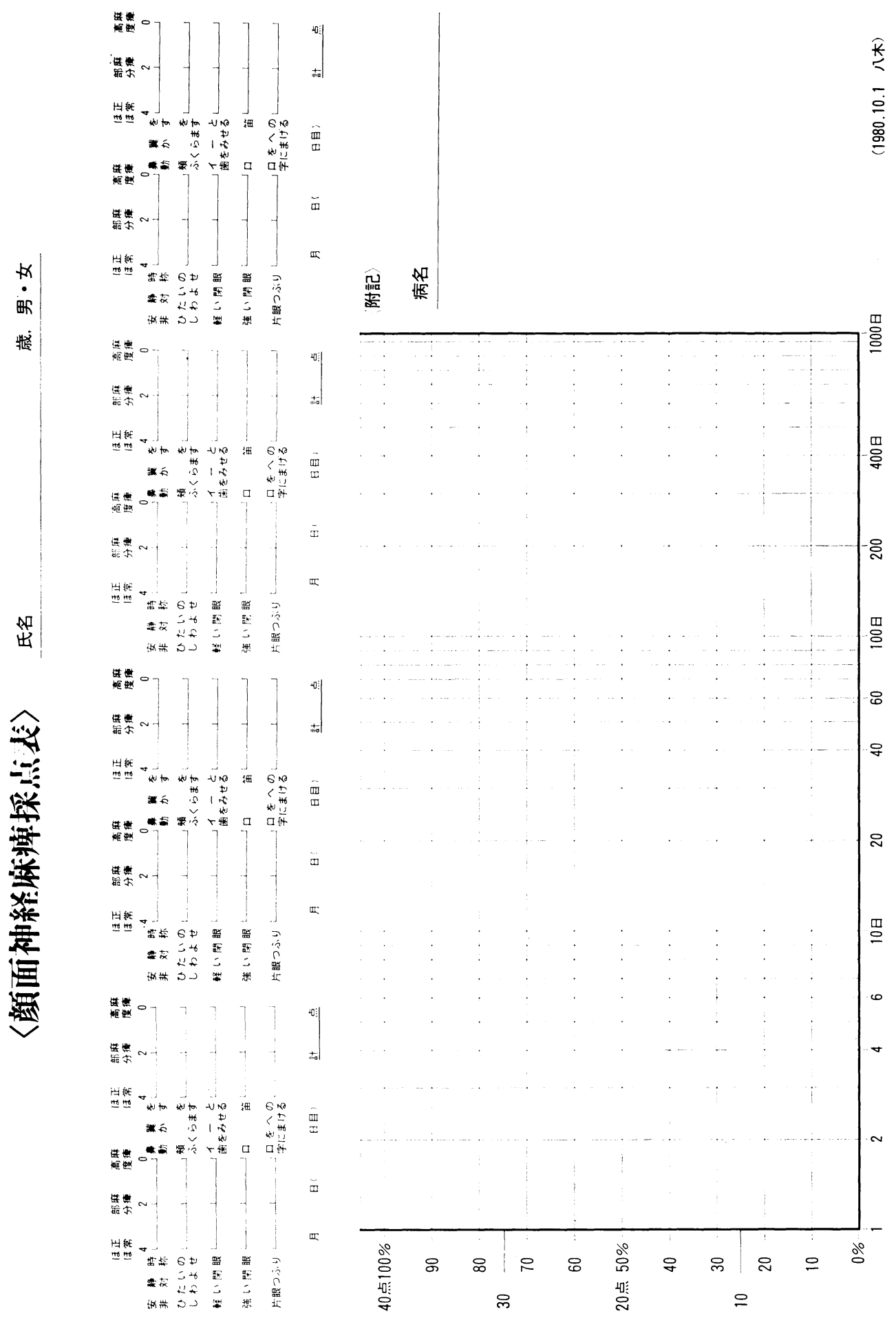




\section{参考 文 献}

1）柳原尚明：顔配神経検查. 現代の 耳絪呐喉科. p. 198-208, 桧学編. 金原出版. 1981.

2) Jepsen. O: Topognosis (Topographic diagnosis) of Facial Nerve Lesion. Arch. otolaryg. 81 : 446-456, 1965.

3) Citron. D. et al. : Acoustic Reflex and Loudness Discomfert in Acute Facial paralysis. Arch. otolaryg. 104 : 303-306, 1978.

4) Adour. K. et al.: The true nature of Bell's palsy Analysis of 1,000 consecutive patients. The laryngoscope 88: 787-801, 1978.

5 ) May. M: Facial paralysis, peripheral type: a proposed method of reporting. The laryngoscope. 80 : 331-390, 1970.

6）八木伸也，他：末梢顔面神経㑣晫之糟分筋電汹。 耳鼻臨休. $73: 1355-1361,1980$.

7 ) 廣谷速人 : 神経縫合術, 整形外科 Mook No 19 : 末梢神経損傷. p. 115-126 野村進編. 金原出版 1981.

8 ) Seddon, H. J : Three types of nerve injury. Brain 66 : 237-288, 1943.

9 ) Sunderland, S: A classification of peripheral nerve injuries producing loss of function. Brain 74 : 491-516, 1951.

10）東田紀彦：治療才j針一手術の適応と手術時期一。 整形外科 Mook No 19. p. 94-105

11) 野村 進: 神経の再生, 整形外科 Mook No 19 . p. $36-48$

12）森 雅文: 末梢神経の変性. 整形外科 Mook No 19 p. $27-35,1979$.

13）山本長三郎：臨休医家に必装な末梢神経の生理学. 整形外科 Mook No 19.: p. 18-26, 1979.

14）黑川正則：軸委流概挽. 腿科 Mook No 9. 金原 出版 p. 114-124, 1979.

15) Grafstein. B., et al.: Intracellual transport in neurons. Physiological Review 60: 4: 1167 1283, 1980.

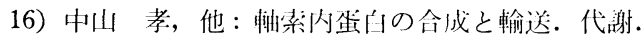
vol 18, No 6: p. 25-32, 1981.

17）小宮義章，他：軸采内輸送. 蚠白質核酸酵素. vol. 22 : No 6 : p. 545-553, 1977.

18) Kreuzberg. G. W : Aspekte der Zellbiologie und Zell patologie des Neurons. ノイロンの細 胞生物学. 細胞病理学展望. 狭間龺忠他訳. 金原 堂. 1975.

19) Kreuzberg, G. W: Changes in axonal flow during regeneration of mammalian motor nerves. Acta. neuropath (Berl) Sup : 70-75, 1971.

20) Minatogawa. T. et al.: The blood supply of the facial nerve in the human temporal bone. Auris. Nasus. Larynx. (Tokyo). $7: 7-18,1980$.

21) Sunderland, $S$ et al.: The Structure of the Facial Nerve. Anat. Rec. 116 : 147-162, 1953.

22) Sunderland, S. : Some anatomical and pathophysiological data relevant to facial nerve injury and repair. Facial Nerve Surgery ed. by U. Fisch. Kugler Medical Pub. 1977.

23) Van. Buskirk. C: The seventh nerve complex. J. Com. Neuro., 82 : 303-333, 1945.

24) Kullman. G. L., et al.: Anatomy of the mastoid portion of the facial nerve. Arch. otolaryng. 93 : 20-33, 1971.

25）村上信五，他：アブミ骨筋神経の空間的配列につ いて. Ear Res Jpn 13 : 263-266, 1982.

26) Blunt. M. J.: The blood supply of the facial nerve. J. anatomy. 88 : 520-526, 1943.

27) Crow, S. J. et al. : Observations on the pathological high tone deafness. Bull. Jhons. Hopkins. Hos. : 54 : 3151934.

28）柏木 力：医学統計解析. 朝倉書店. 1979.

29）細見英男，他：末梢性顔面神経麻痺の治癒状態の 判定について.耳鼻臨休. 67 : 351-358, 1974.

30) 柳原尚明, 他：顔面神経麻痺程度の判定基準に関 する研究。山耳鼻. 80: 799-805, 1977.

31）渡 正堯, 他：多変量解析プログラム集. 工学図 棺, 1981 .

32) Lippold, O. C. J.: The relation between Integrated Acticn Potentials in a Human Muscle and its Isometric Tension. J. Physiol. 117 : 492-499, 1952.

33）八木伸也，他：末梢性顔面神経麻脾にお打る耳小 冎筋反射。耳鼻臨休．75：317-372, 1982.

34) 野尻 功：人のアブミ骨筋の神経支配. 解剖学雑 誌. 38 : 4-5. : 212-231, 1963. 
35) 下沢淳海：カニクイザル顔面神経の有髄神経線維 について. 解剖学雑誌. 43: 73-88, 1968.

36) Bruesh. S. R: The distribution of myelinated afferent fibers in the branches of the cat's facial nerve. J. comp. neuro. 81: 169-191, 1944.

37）八木伸也，他：末梢性顔面神経麻㽻の流涙テスト. 耳鼻臨床. $74: 1817-1825,1981$.

38）粟橋克昭, 他：顔面神経機能検查における流涙テ ストの再検討. 耳鼻臨休．68：535-541， 1975.
39）東辻英郎：顔面神経麻䞄の子後診断に打ける顎下 腺唾液流量検查の有用性.耳鼻臨床．74：657697, 1981.

40)友出幸一, 他：顔面神経麻痺部位診断への $67 \mathrm{Ga}$ のシンチグラムの応用経験. 耳鼻臨休. 74：283288, 1981.

$\left(\begin{array}{l}\text { 別刷請求先 : 八木伸也 } \\ \bar{T} 910 \text { 福井市月見 } 2 丁 \text { 丁 } 4 \text { 番 } 1 \text { 号 } \\ \text { 福井赤十字病院耳鼻咽㮢科 }\end{array}\right)$ 